\title{
KEDUDUKAN KELEBIHAN HARTA WARISAN (RADD) UNTUK JANDA DAN DUDA DALAM HUKUM WARIS ISLAM
}

\author{
Iwan Setyo Utomo \\ NOTARIS / PPAT Didik Ponco Sulistyono, S.H., M.Kn. \\ Ruko Anggrek sari Alexandria Blok B8 No. 50, Batam \\ Email: iwan_emailq@yahoo.com
}

\begin{abstract}
This study aims to find out how current legal devices could give legal certainty on excess of family heritage partition (radd) for widowers and widows in Islamic laws as well as analyse judicial consideration on which matters regarding excess of family heritage partition (radd) for widower and widow are based.The writer used normative law method which consists of statute approach and conceptual approach.The comprehension of radd in Islamic scholars views differ from each other in terms of heirs. Some scholars accept the concept of radd whereas some do not. Scholars who do not accept radd base their views on An-Nisa verse 14 and hadiths which state that radd should be given to baitul mal as Muslims representative. On the other hand, scholars who accept the concept of radd refer their arguments to Al-Anfal verse 75 and hadiths which state that kinship has more influence to inheritance matter rather than relations based on religions or marriages. Nevertheless, scholars who accept radd also differ from each other in terms who has the right to receive radd. The matters of radd have been regulated on article 193 of Islamic Law Compilation (KHI). Radd should be given to all heirs with no exception including husband (widower) or wife (widow). Based on rational thinking, husband (widower) or wife (widow) are allowed to receive radd since under no circumstances is husband or wife unable to give heritage to their wife or husband. However, in different context and cases, it can be reconsidered without setting aside scholars arguments.
\end{abstract}

Key words: heir, radd, widow, widower

\begin{abstract}
Abstrak
Tulisan ini bertujuan untuk mengetahui dan memperbaharui sejauh mana perangkat hukum yang ada mampu memberikan kepastian hukum kedudukan kelebihan pembagian harta warisan ( radd) untuk janda dan duda dalam hukum waris Islam dan menganalisis tentang pertimbangan yuridis yang dijadikan dasar pertimbangan dalam memutus perkara yang terkait dengan kelebihan pembagian harta warisan ( $r a d d)$ untuk janda dan duda. Penulis menggunakan metode hukum normatif yang terdiri dari pendekatan undang-undang (statue approach) dan pendekatan konseptual (conceptual approach). Pemahaman konsep radd dalam pandangan para ulama memiliki perbedaan mengenai ahli waris penerima radd. Ada ulama yang menerima radd dan ada juga yang menolak radd. Ulama yang menolak radd berdasakan Surat An-Nisa ayat 14 dan hadits, yaitu radd diserahkan kepada baitul mal sebagai perwakilan dari umat Islam. Sedangkan ulama yang menerima radd memperkuat argumennya dengan dalil surat Al-Anfal ayat 75 dan hadits, yaitu hubungan kekerabatan nasab jauh lebih berpengaruh dalam kewarisan dibandingkan dengan hubungan agama atau perkawinan. Karena dipandang lebih maslahah dan dapat membantu kehidupan keluarganya. Ternyata ulama yang menerima radd juga menimbulkan perbedaan tentang siapa saja ahli waris yang berhak menerima radd. Masalah
\end{abstract}


radd diatur dalam pasal 193 Kompilasi Hukum Islam (KHI). Radd diberikan kepada semua ahli waris tanpa kecuali, termasuk suami (duda)/istri (janda). Secara lebih rasional suami (duda)/ istri (janda) boleh menerima radd, karena dalam keadaan apapun tidak mungkin seorang suami (duda)/istri (janda) terhalang mewaris atau terhijab

Kata kunci: ahli waris, radd, janda, duda

\section{Latar Belakang}

Indonesia merupakan negara yang berbhineka tunggal ika yang terdiri dari berbagai macam suku, bahasa, budaya, adat istiadat dan agama. Agama dan keyakinan kepercayaan yang ada di Indonesia sangat dihargai dan dilindungi seiring dengan dasar negara yang tertuang dalam sila pertama pancasila bahwa negara berdasarkan Ketuhanan Yang Maha Esa, dan diperjelas pada Pasal 29 ayat (1) Undang-Undang Dasar NRI Tahun 1945, sedangkan Republik Indonesia adalah negara yang berdasarkan atas Ketuhanan Yang Maha Esa. Berdasarkan Pasal 29 ayat (1) Undang-Undang Dasar Dasar NRI Tahun 1945 ini berarti semua peraturan perundang-undangan di Indonesia tidak boleh ada yang bertentangan dengan ajaran Tuhan Yang Maha Esa.

Indonesia bukan negara berideologi agama namun hampir mayoritas penduduk Indonesia memeluk agama Islam. Dibandingkan dengan negara-negara lain, Indonesia menempati posisi sebagai negara dengan penduduk yang memeluk agama Islam terbesar di dunia. Hukum Islam adalah bagian dari ajaran agama Islam. Ajaran Islam merupakan suatu sistem yang terdiri dari akidah, akhlak, dan syariah. ${ }^{1}$ Hal ini jelas bahwa negara menjamin kebebasan beragama bagi warga negaranya.

Dalam perkembangannya aturan-aturan maupun hukum Islam dijadikan sebagai pedoman dan dasar kehidupan berbangsa, bernegara dan bermasyarakat dalam kehidupan masyarakat kita selain dasardasar hukum positif lainnya. Maka hukum islam mempunyai peranan yang sangat penting dalam masyarakat, terutama untuk menyelesaikan masalah-masalah yang belum diatur secara jelas dalam hukum positif di negara kita.

Menurut aturan agama Islam segi kehidupan manusia dapat dikelompokkan menjadi dua kelompok. Pertama, hal-hal yang berkaitan dengan hubungan dengan Allah SWT penciptanya, aturan hal ini disebut dengan hukum ibadat. Tujuannya untuk menjaga hubungan antara hamba dengan penciptanya. Kedua, berkaitan dengan hubungan antar manusia dan alam sekitarnya. Dasar hukum Islam adalah Al-Qur'an, sunnah rasul dan Ijtihad. Tetapi fuqaha atau ahli hukum Islam sering berbeda pendapat dalam memahami konsep kunci yang termaktub dalam kedua sumber hukum Islam tersebut, sebagai akibatnya timbulah berbagai macam

1 Afdol, Legislasi Hukum Islam di Indonesia, (Surabaya: Erlangga University Press, 2009), hlm. 3. 
aliran atau mazhab fiqih, empat diantaranya yang terkenal adalah mazhab Hanafi, Maliki, Syafii, dan Hambali. Dalam perkembanganya hukum Islam yang mengatur masalah muamalah diatur dalam Kompilasi Hukum Islam dan dijadikan hukum positif melalui Instruksi Presiden No. 1 Tahun 1991 tentang Pelaksanaan Kompilasi Hukum Islam (selanjutnya disebut KHI) yang mengatur masalah hukum perkawinan, kewarisan, wasiat, hibah, wakaf dan shodaqoh. Diantara hubungan sesama manusia (muamalah), hal yang seringkali menimbulkan permasalahan adalah masalah kewarisan dalam hukum waris Islam di Indonesia.

Hukum waris merupakan masalah yang penting dan perlu diperhatikan dalam hukum Islam. Hal tersebut karena masalah kewarisan kemungkinan akan dialami oleh setiap orang. Menurut para fuqaha hukum kewarisan Islam, ialah ilmu yang menjelaskan mengenai orang yang berhak menerima pusaka, orang yang tidak berhak menerima pusaka, serta kadar atau bagian yang diterima setiap ahli waris dan cara membaginya. ${ }^{2}$

Hukum waris Islam bersumber pada $\mathrm{Al}$ Qur'an, yaitu Surat An Nisaa ayat 7, ayat 11 , ayat 12 , ayat 33 dan ayat 176. Dengan dasar 5 (lima) ayat tersebut, diharapkan dapat menyelesaikan mengenai masalah kewarisan Islam. Selain dari Al Qur'an, sumber hukum waris Islam dapat diambil dari hadits Nabi dan ijtihad, dengan maksud dapat melengkapi penjelasan tentang hukum waris Islam tersebut. Di dalam hukum waris Islam hal-hal yang diatur adalah masalah bagaimana pengaturan harta peninggalan dari pewaris harus diberlakukan, kepada siapa saja harta peninggalan pewaris itu dipindahkan dengan tujuan untuk mempermudah dalam menentukan ahli waris yang berhak mendapatkan warisan dan yang tidak berhak mendapatkan warisan serta bagaimana pengaturan tata cara dan perpindahan harta peninggalan tersebut.

Seseorang berhak mendapatkan warisan atau mewaris menurut hukum waris Islam disebabkan karena adanya hubungan perkawinan dan kekerabatan serta memerdekakan budak. Sedangkan yang menghalangi seseorang dalam mendapatkan warisan atau mewaris adalah pembunuhan, berlainan agama, perbudakan dan berlainan negara.

Salah satu masalah yang sering muncul dalam hukum waris Islam adalah sistem pembagian harta peninggalan atau warisan, yaitu mengenai siapa saja ahli waris yang berhak mendapatkan warisan dalam jumlah bagian kadar masing-masing. Dalam hukum waris Islam, sistem pembagian harta warisan tentunya berbeda dengan sistem pembagian harta warisan dalam sistem hukum adat maupun hukum perdata. Dalam hukum waris Islam juga dikenal istilah aul yaitu pembagian harta peninggalan atau warisan yang akan dibagikan kepada para ahli waris jika terdapat kekurangan harta, sedangkan

2 Hasbi Ash-Shiddieqy, Fiqhul Mawaris, (Jakarta: Bulan Bintang, 1973), hlm. 18. 
yang terdapat kelebihan harta dinamakan dengan radd. Dalam penelitian ini penulis lebih memfokuskan pada ahli waris yang berhak menerima adanya sisa (kelebihan) harta peninggalan atau warisan yang sudah ditentukan, secara lazim disebut dengan radd.

Sisa (kelebihan) harta peninggalan atau warisan ini tentunya akan menimbulkan suatu perselisihan jika tidak diatur secara jelas mengenai siapa-siapa ahli waris yang berhak menerimanya serta penyebab adanya masalah radd. Mengenai aturan hukum waris Islam khususnya mengenai masalah radd diatur dalam Kompilasi Hukum Islam (KHI) Pasal 193, yaitu:

"Apabila dalam pembagian harta warisan diantara para ahli waris dzawil furudh menunjukkan bahwa angka pembilang lebih kecil daripada angka penyebut, sedangkan tidak ada ahli waris ashabah, maka pembagian harta warisan tersebut dilakukan secara radd, yaitu sesuai dengan hak masing-masing ahli waris sedangkan sisanya dibagi berimbang diantara mereka."3

Dalam hukum waris Islam mengenai penyelesaian kelebihan sisa harta warisan secara radd ternyata ada perbedaan pendapat diantara para ulama maupun ahli hukum waris Islam sebagian ulama ada yang tidak setuju sama sekali, ada juga sebagian yang menyetujui dengan syarat, dan sebagian lagi secara tegas menerimanya. Di bawah ini adalah beberapa pendapat para ulama mengenai masalah radd, yaitu:

1. Pendapat Zaid bin Tsabit, diikuti oleh 'Urwah,Az-Zuhri, MalikdanAsy-Syafi'i; ${ }^{4}$ Mereka memberi penjelasan bahwa tidak ada radd terhadap seorangpun ahli waris (ashabul furudh) dan jika tidak ada ahli waris ashabah sisa (kelebihan) hartanya itu diserahkan kepada baitul maal.

2. Pendapat Utsman bin Affan; ${ }^{5}$ Beliau berpendapat bahwa adanya radd untuk semua ahli waris (ashabul furudh) termasuk kepada istri (janda) dan suami (duda) menurut kadar bagian masingmasing.

Pendapat Ali bin Abi Thalib, 'Umar, jumhur sahabat dan tabi'in, mahzab Abu Hanifah, Ahmad dan pendapat yang dipegang aliran Syafi'i serta sebagian pengikut Malik ketika baitul mal rusak; ${ }^{6}$ Mereka berpendapat bahwa radd akan diberikan kepada semua ahli waris (ashabul furudh), kecuali janda dan duda serta ayah dan kakek.

Dalam KHI Pasal 193, sisa (kelebihan) harta peninggalan atau warisan dapat diselesaikan secara radd dan radd dapat

3 Fathur Rachman, Ilmu Waris, (Bandung: Al-Ma'rif, 1975), hlm. 427.

4 Komite Fakultas Syari'ah Universitas Al-Azhar Kairo, Hukum Waris, Terjemahan Addys al-Alizar, Fathurrahman, (Jakarta: Senayan Abadi Publishing, 2004), hlm. 322.

5 Ibnu Qudamah, Al-Mughni, Juz 7, (Beirut: Dar al-Kutub al-Ilmiyah, t.th), hlm. 46. Lihat juga Hasan Yusuf Ghazali, Al-Miras ala al-Mazahibul Arba'ah dirasatan watatbikhan, (Ttp: Daar al-Fikr, 2003), hlm. 113. Lihat juga Abdul Hamid, Muhammad Muhyiddin, Ahkam Al-Mawarits fi Al-Syari'ah Al-Islamiyah 'ala Madhahib Al-Arba'ah, Terjemahan Wahyudi Abdurrahim, (Jakarta: Pustaka al-Kautsar, 2006), hlm. 239.

6 Akhmad Kuzari, Sistem Asabah: Dasar Pemindahan Hak Milik atas Harta Tinggalan, (Jakarta: RajaGrafindo Persada, 1996), hlm. 167. 
diberikan kepada semua ashabul furudh, tanpa dijelaskan suami ataupun istri termasuk sebagai ahli waris yang diperbolehkan menerima radd. Selain itu ada sebagian pendapat yang menyatakan bahwa radd dapat diberikan kepada semua ashabul furudh kecuali suami dan istri. Berikut ini adalah 8 asbahul furudh yang berhak menerima radd:

a. Anak perempuan.

b. Cucu perempuan.

c. Saudara perempuan sekandung.

d. Saudara perempuan sebapak.

e. Saudara perempuan seibu.

f. Saudara laki-laki seibu.

g. Ibu.

h. Nenek yang shahih.

Adapun untuk ayah dan kakek walaupun termasuk ahli waris (ashabul furudh) dalam beberapa keadaan, tetap tidak boleh menerima radd. Apabila terdapat ayah dan kakek, maka masalah radd tidak mungkin akan terjadi, karena keduanya menjadi ahli waris (ashabah) dan mengambil sisanya.

Ahli waris (ashabul furudh) yang tidak boleh menerima radd adalah suami (duda) dan istri (janda) saja, karena hubungan kekerabatan mereka bukan kekerabatan nasabiyah (hubungan darah) tetapi kekerabatan sababiyah (hubungan perkawinan). Sehingga hak suami dan istri hanya dapat mengambil bagiannya saja tanpa mendapat tambahan, hal ini karena terputus oleh kematian. Dan sisanya ia kembalikan lagi kepada ahli waris lainnya.

Menurut KHI yang mengatur tentang bagian waris duda, terdapat pada pasal 179 , yaitu:
"Duda mendapat separuh bagian, apabila pewaris tidak meninggalkan anak, dan apabila pewaris meninggalkan anak, duda mendapat seperempat bagian.”

Sedangkan bagian janda terdapat pada pasal 180, yaitu:

"Janda mendapat seperempat bagian apabila pewaris tidak meninggalkan anak dan apabila pewaris meninggalkan anak, janda mendapat seperdelapan bagian."

Pasal 179 dan pasal 180 tersebut hanya menjelaskan mengenai bagian waris janda dan duda secara umum tanpa menjelaskan tentang sisa (kelebihan) harta atau radd. Masalah sisa (kelebihan) harta atau radd dalam pembagian harta warisan ini akan menimbulkan suatu perselisihan dalam hal ahli waris, jika tidak diatur secara jelas mengenai siapa-siapa ahli waris yang berhak menerimanya apalagi menyangkut jumlah harta tersebut tergolong besar.

\section{Pembahasan}

\section{A. Munculnya Radd}

Tidak ada nash secara khusus dalam Al Qur'an ataupun Sunah Rasul tentang radd. Oleh karena itu terdapat perbedaan pendapat diantara para ulama tentang radd. Pada prinsipnya perbedaan pendapat para ulama adalah ada atau tidak adanya radd. Masalah radd muncul karena adanya sisa (kelebihan) harta setelah dibagikan serta tidak adanya 
ashabah. Munculnya radd ini bertujuan untuk mengembalikan sisa (kelebihan) harta warisan tersebut kepada ahli waris dzawil furudh sesuai dengan kadar bagian masing-masing. Radd terjadi jika memenuhi 3 (tiga) rukun, yaitu terwujudnya ahli waris ashabul furudh, terwujudnya kelebihan (sisa) harta warisan, dan tidak adanya ahli waris ashabah.

Pendapat para ulama yang menerima adanya radd adalah sebagai berikut:

1. Pendapat Ali bin Abi thalib r.a. dan Umar bin Khattab r.a.

Radd akan diberikan kepada ahli waris ashabul furudh, kecuali suami, isteri, ayah dan kakek pewaris. Karena suami dan istri bukanlah hubungan kekerabatan nasab. Dasar hukum yang menjadi pedoman mereka adalah Al Qur'an surat Al Anfal ayat 75, yang artinya:

"dan orang-orang yang memiliki hubungan kekerabatan itu sebagiannya lebih berhak daripada yang lainnya".

Demikian juga sabda Nabi Muhammad SAW, ketika seorang perempuan mendatangi beliau dengan satu pertanyaan mengenai status budak yang dia serahkan kepada ibunya dalam beberapa hari kemudian ibunya meninggal dunia, yaitu bahwa budak tersebut berhak atau tidak dalam menerima pahala melalui jalan pewarisan.

\section{Pendapat Utsman bin Affan r.a.}

Radd adalah kelebihan (sisa) harta peninggalan atau warisan yang dikembalikan kepada seluruh ahli waris (ashabul furudh) yang ada tanpa terkecuali, termasuk kepada suami istri menurut bagian mereka masingmasing. ${ }^{7}$

\section{Pendapat Muslich Maruzi}

Kelebihan (sisa) harta warisan atau radd tersebut jika terjadi keadaan dimana jumlah semua bagian ahli waris ternyata lebih sedikit daripada jumlah harta warisan yang ada (harta warisan lebih banyak daripada jumlah bagianbagian ahli waris). ${ }^{8}$

4. Pendapat ulama Syafi'iyah (Ibnu Saraqah, Qadi al-Husain al-Mutawally)

Bahwa kelebihan (sisa) harta atau radd sebaiknya dikembalikan saja kepada ahli waris ashabul furudh atau dzawil arham jika ada, secara proporsional. ${ }^{9}$

5. Pendapat Abdullah Ibnu Mas'ud

Radd dikembalikan kepada ahli waris dzawil furudh kecuali 7 (tujuh) ahli waris (ashabul furudh) orang, diantaranya suami atau istri, cucu perempuan garis laki-laki jika ada anak perempuan, saudara perempuan seayah jika bersama saudara perempuan sekandung, saudara-saudara seibu apabila bersama ibu, nenek jika ada dzawil furudh yang lebih berhak. ${ }^{10}$ Dalam hal ini Ibnu

7 Abdul Hamid dan Muhammad Muhyiddin, Ahkam Al-Mawarits fi Al-Syari'ah Al-Islamiyah 'ala Madhahib AlArba'ah, Terjemahan Wahyudi Abdurrahim, (Jakarta: Pustaka al-Kautsar, 2006), hlm. 239.

8 Fatchur Rahman, Ilmu Waris, dikutip dari Ahmad Rofiq, op.cit., hlm. 103.

9 Muhammad Ali As-Shabuni, Ilmu Hukum Waris Menurut Ajaran Islam, (Surabaya: Mutiara Ilmu, 1388), hlm. 109-110.

10 Ahmad Rofiq, Hukum Islam di Indonesia, (Jakarta: RajaGrafindo Persada, 2003), hlm. 434. 
Mas'ud (yang diikuti oleh Alqamah dan Imam Ahmad bin Hanbal) mengutamakan ahli waris yang berhak menerima radd adalah ahli waris yang terdekat. Sebagai contoh Nenek, yaitu nenek dekat dengan pewaris karena ada perantara perempuan lain (ibu) sehingga membatasi nenek untuk mendapatkan hak waris. Dengan demikian nenek tidak berhak mewaris daripada ahli waris yang mempunyai hubungan kekerabatan yang lebih kuat.

6. Pendapat Imam Ahmad bin hanbal dan Imam Abu Hanifah

Bahwa kelebihan (sisa) harta atau radd setelah dibagikan kepada ahli waris ashabul furudh, maka akan diberikan kepada ahli waris ashabul furudh senasab kecuali suami dan istri, baik baitul maal yang terorganisir secara adil maupun tidak, sehingga wajib diberikan kepada ahli waris ashabul furudh.

7. Pendapat Syi'ah Zaidiyah dan Imamiyah Bahwa kelebihan (sisa) harta akan diserahkan kepada ahli waris yang ada sesuai dengan kadar bagian masing-masing. Pertama, kelebihan (sisa) harta akan diberikan kepada suami bukan kepada istri. Kedua, kelebihan (sisa) harta akan diserahkan kepada suami atau istri secara mutlak dalam semua keadaan. Ketiga, kelebihan (sisa) harta diberikan kepada suami atau istri manakala tidak ada imam yang adil, walaupun ada imam yang adil maka kelebihan (sisa) harta akan diserahkan kepada suami. ${ }^{11}$

8. Pendapat Ibnu Abbas

Kelebihan (sisa) harta akan diberikan kepada ahli waris (ashabul furudh) selain suami ataupun istri serta nenek. Jika bersama ahli waris ashabulfurudh, maka yang memiliki hubungan kekerabatan nasab. Jika tidak ada, maka boleh mendapat pengembalian. Karena itulah nenek tidak boleh mendapat bagian lebih dari apa yang telah ditetapkan, kecuali jika tidak ada ahli waris ashabul furudh yang memiliki hubungan kekerabatan karena nasab. ${ }^{12}$ Adapun hadits Rasulullah SAW yang digunakan Ibnu Abbas untuk memperkuat pengecualiannya terhadap nenek, yaitu:

"Dari Ibnu Buraidah r.a. yang
menerangkan bahwa Nabi
Muhammad SAW menjadikan
bagian seperenam untuk nenek, jika
tidak didapati ibu bersamanya (HR.
Abu Daud)".

Dari penjelasan hadits tersebut, maka nenek tidak boleh mendapat bagian lebih dari apa yang telah ditetapkan, kecuali jika tidak ada ahli waris dzawil furudh yang memiliki hubungan kekerabatan nasab.

Sedangkan pendapat para ulama atau fuqaha yang menolak adanya radd adalah:

1. Pendapat Zaid bin Tsabit, Urwah ibnu Zubeir, dan Sulaiman ibnu Yasar

Kelebihan (sisa) harta warisan setelah diambil dari ahli waris ashabul furudh akan diserahkan kepada Baitul Mal untuk kepentingan masyarakat Islam. Pendapat tersebut memiliki beberapa alasan yang kuat, yaitu:
a. Terdapat dalam Al Qur'an Surat An Nisaa ayat 13 dan 14, yang artinya:

11 Muhammad Jawad Mughniyah, Fiqih Lima Mahzab, Terjemahan Afif Muhammad, (Jakarta: Basri Press, 1994), hlm. 357.

12 Ibid., hlm. 173. 
“(Hukum-hukum tersebut) itu merupakan ketentuan dari Allah SWT. Barangsiapa taat kepada Allah SWT dan Rasul-Nya, niscaya Allah memasukkannya ke dalam surga yang mengalir di dalamnya sungaisungai, sedangkan mereka kekal di dalamnya. Dan itulah kemenangan besar. Dan barangsiapa yang mendurhakai Allah dan Rasul-Nya dan melanggar ketentuan-Nya, niscaya Allah memasukkannya ke dalam api neraka sedangkan ia kekal di dalamnya. Dan baginya siksa yang menghinakan."

b. Nabi SAW menegaskan, bahwa: "Allah telah memberi bagian kepada yang berhak sesuai dengan haknya." (Riwayat Al Tirmidzi)

c. Ahli waris yang telah menerima bagian, tidak memiliki jalan lain untuk menerimanya. ${ }^{13}$

2. Pendapat Imam Syafii dan Imam Maliki Sisa (kelebihan) harta setelah dibagikan kepada ahli waris ashabul furudh, maka radd tidak bisa dikembalikan kepada ahli waris ashabul furudh, tetapi harus diserahkan kepada baitul maal. ${ }^{14}$ Demikian pula tidak boleh diserahkan kepada ahli waris dzawil arham, baik untuk kas baitul maal teratur dalam melaksanakan tugasnya ataupun tidak. Oleh karena itu, kelebihan (sisa) harta setelah dibagikan kepada ahli waris $d z u l$ furudh tidak dapat dimiliki oleh seorang ahli waris karena tidak ada jalan untuk memilikinya dan harus diserahkan ke baitul maal.

\section{B. Penyelesaian Masalah Radd}

Penyelesaian masalah radd ada 4 (empat) cara atau hukum tersendiri, yaitu:

1. Adanya pemilik bagian yang sama (tanpa suami atau istri)

Pembagian harta warisan secara langsung dapat dibagikan merata kepada seluruh ahli waris berdasarkan jumlah bagian mereka dengan cara yang mudah dan dalam waktu yang singkat. Misalnya: si pewaris meninggalkan tiga anak perempuan, maka harta peninggalan tersebut dibagikan sesuai jumlah ahli waris. Bagian mereka sesuai fardh yaitu 2/3, dan sisanya diselesaikan secara radd. Jadi pembagian hak waris masingmasing sesuai dengan jumlah mereka. Contoh kasusnya adalah:

Pewaris meninggalkan harta sejumlah Rp. 12.000.000,-. Ahli warisnya terdiri dari ibu. Maka berapakah bagian ibu?

Tabel 1. Contoh Kasus Penghitungan Radd 1

\begin{tabular}{ccccc}
\hline Ahli Waris & Bagian & AM (6) & HW (Rp. 12.000.000,-) & \multicolumn{1}{c}{ Penerimaan } \\
\hline Ibu & $1 / 3$ & 2 & $2 / 6 \times$ Rp 12.000.000 & $=R p 4.000 .000,-$ \\
\hline \multicolumn{7}{c}{ Maka sisa harta Rp 12.000.000 - Rp 4.000.000 = Rp 8.000.000 (sisa ini akan diberikan kepada ibu) } \\
\hline
\end{tabular}

Sumber: Data Primer, diolah, 2017

13 Muhammad Jawad Mughniyah, op.cit., hlm. 436-437.

14 Ibid., hlm. 327. 
2. Adanya pemilik bagian yang berbeda (tanpa suami atau isteri)

Harta peninggalan dibagikan berdasarkan jumlah bagian ahli waris, bukan pada jumlah mereka. Sebagai contoh, pewaris meninggalkan satu anak perempuan (1/2) dan satu cucu perempuan pihak anak lakilaki (1/6). Berdasarkan jumlah bagian kedua ahli waris tersebut adalah empat (4). Karena berdasarkan dari hasil penjumlahan yang tadinya 6 berubah menjadi 4. Contoh kasusnya adalah:

Pewaris meninggalkan harta sejumlah Rp 12.000.000,-. Ahli warisnya terdiri dari ibu dan dua saudara seibu. Maka berapakah bagian ibu dan dua saudara seibu?

Tabel 2. Contoh Kasus Penghitungan Radd 2

\begin{tabular}{lccccc}
\hline \multicolumn{1}{c}{ Ahli Waris } & Bagian & AM (6) & HW (Rp 12.000.000,-) & \multicolumn{2}{c}{ Penerimaan } \\
\hline Ibu & $1 / 6$ & 1 & $1 / 6 \times \mathrm{Rp} \mathrm{12.000.000,-}$ & $=\mathrm{Rp} 2.000 .000,-$ \\
\hline 2 saudara seibu & $1 / 3$ & 2 & $2 / 6 \times \mathrm{Rp} 12.000 .000,-$ & $=\mathrm{Rp} 4.000 .000,-$ \\
\hline
\end{tabular}

\section{Sumber: Data Primer, diolah, 2017}

3. Adanya pemilik bagian yang sama satu, dan mengenai sisanya tiga perempat (ternasuk suami atau istri)

Harta peninggalan dibagikan kepada ahli waris yaitu yang tidak menerima radd suami (duda) atau istri (janda) dan sisanya kemudian dibagikan kepada ahli waris lain (ashabah) sesuai dengan jumlah mereka. Misalnya: pewaris meninggalkan ahli waris suami dan 2 anak perempuan. Maka suami berhak memperoleh seperempat (1/4) bagian berarti (3/4) bagian dibagikan secara merata kepada kedua anak perempuan tersebut. Contoh kasusnya adalah:

Pewaris meninggalkan harta sejumlah Rp 12.000.000,-. Ahli warisnya adalah suami atau duda dan dua anak perempuan. Maka berapakah bagian suami dan dua anak perempuan?

Tabel 3. Contoh Kasus Penghitungan Radd 3

\begin{tabular}{lccccc}
\hline \multicolumn{1}{c}{ Ahli Waris } & Bagian & AM(4) & HW (Rp 12.000.000,-) & \multicolumn{2}{c}{ Penerimaan } \\
\hline Suami & $1 / 4$ & 1 & $1 / 4 \times \mathrm{Rp} \mathrm{12.000.000,-}$ & $=\mathrm{Rp} 3.000 .000,-$ \\
\hline 2 anak perempuan & $3 / 4$ & 3 & $3 / 4 \times \mathrm{Rp} 12.000 .000,-$ & $=\mathrm{Rp} 9.000 .000,-$ \\
\hline
\end{tabular}

Sumber: Data Primer, diolah, 2017

4. Adanya pemilik bagian yang berbeda (termasuk suami atau istri)

Pembagian harta peninggalan dengan 2 cara, yaitu pertama, berdasarkan susunan ahli warisnya tanpa ada duda atau janda dan yang kedua, berdasarkan susunan ahli warisnya ada duda ataujanda. Selanjutnya dapat diselesaikan dengan melihat 3 perihal pembanding yaitu tama'atsul (kemiripan), tawa'afuq (sepadan), dan taba'ayun (perbedaan). Contoh kasusnya adalah: 
Pewaris meninggalkan harta sejumlah Rp dan saudara seibu. Maka berapakah bagian 24.000.000,-. Ahli warisnya adalah istri, ibu istri, ibu dan saudara seibu?

Tabel 4. Contoh Kasus Penghitungan Radd 4

\begin{tabular}{lccccc}
\hline \multicolumn{1}{c}{ Ahli Waris } & Bagian & AM (12-6) & HW (Rp 24.000.000,-) & Penerimaan \\
\hline Janda & $1 / 4$ & 3 & $3 / 12 \times \mathrm{Rp} \mathrm{24.000.000,-}$ & $=\mathrm{Rp} 6.000 .000,-$ \\
\hline Ibu & $1 / 6$ & 2 & $2 / 12 \times \mathrm{Rp} \mathrm{24.000.000,-}$ & $=\mathrm{Rp} 4.000 .000,-$ \\
\hline Saudara seibu & $1 / 3$ & 4 & $4 / 12 \times \mathrm{Rp} 24.000 .000,-$ & $=\mathrm{Rp} 8.000 .000,-$ \\
\hline
\end{tabular}

(sisa harta $\mathrm{Rp} 24.000 .000-\mathrm{Rp} 18.000 .000=\mathrm{Rp}$ 6.000.000) Sisa harta tersebut diberikan kepada ibu dan saudara seibu

\begin{tabular}{lllcl}
\hline Ibu & $1 / 6$ & 1 & $1 / 3 \times \mathrm{Rp} \mathrm{6.000.000,-}$ & $=\mathrm{Rp} 2.000 .000,-$ \\
\hline Saudara seibu & $1 / 3$ & 2 & $2 / 3 \times \mathrm{Rp} \mathrm{6.000.000,-}$ & $=\operatorname{Rp~} 4.000 .000,-$ \\
\hline & & 3 & Jumlah & $=\operatorname{Rp~6.000.000,-}$ \\
\hline
\end{tabular}

Sumber: Data Primer, diolah, 2017

C. Penyelesaian Masalah Radd Untuk 1. Jika seorang suami meninggal dunia Janda dan Duda

Berikut ini adalah contoh perhitungan dalam menyelesaikan masalah radd untuk hanya meninggalkan istri saja. Harta yang ditinggal sejumlah Rp 50.000.000,-. Maka cara penyelesaiannya: janda dan duda, yaitu:

Tabel 5. Contoh Kasus Penghitungan Radd untuk Janda dan Duda 1

\begin{tabular}{ccccc}
\hline Ahli Waris & Bagian & AM (4) & HW (Rp 50.000.000,-) & \multicolumn{1}{c}{ Penerimaan } \\
\hline Isteri (janda) & $1 / 4$ & 1 & $1 / 4 \times$ Rp 50.000.000,- & $=$ Rp 50.000.000,- \\
\hline \multicolumn{7}{c}{ Maka istri tersebut mendapatkan seluruh harta waris 1/4 (karena tidak ada anak) + sisa harta $($ radd $)$} \\
\hline
\end{tabular}

Sumber: Data Primer, diolah, 2017

2. Jika seorang istri meninggal dunia hanya meninggalkan suami saja. Harta yang ditinggal sejumlah $\mathrm{Rp} 25.000 .000,-$. Maka cara penyelesaiannya:

Tabel 6. Contoh Kasus Penghitungan Radd untuk Janda dan Duda 2

\begin{tabular}{ccccc}
\hline \multicolumn{1}{c}{ Ahli Waris } & Bagian & AM (2) & HW (Rp 25.000.000,-) & Penerimaan \\
\hline Isteri (janda) & $1 / 2$ & 1 & $1 / 2 \times$ Rp 25.000.000,- & $=$ Rp 25.000.000,-- \\
\hline \multicolumn{7}{c}{ Maka suami tersebut mendapatkan seluruh harta waris 1/2 (karena tidak ada anak) + sisa harta $($ radd $)$} \\
\hline
\end{tabular}

\section{Sumber: Data Primer, diolah, 2017}

3. Harta peninggalan pewaris sejumlah 36 perempuan. Maka penyelesaiannya hektar sawah. Ahli warisnya adalah suami adalah: (duda), ibu, kakek dan 2 saudara kandung 
Tabel 7. Contoh Kasus Penghitungan Radd untuk Janda dan Duda 3

\begin{tabular}{lcccc}
\hline \multicolumn{1}{c}{ Ahli Waris } & Bagian & AM (6) & HW (36 h.a) & Penerimaan \\
\hline Suami (duda) & $1 / 2$ & 3 & $3 / 6 \times 36$ h.a & $=18$ h.a \\
\hline (sisa harta 36 h.a -18 h.a =18 h.a) & $1 / 6$ & 1 & $1 / 3 \times 18$ h.a & $=6$ h.a \\
\hline Ibu & $1 / 6$ & 1 & $1 / 3 \times 18$ h.a & $=6$ h.a \\
\hline Kakek & $1 / 6$ & 1 & $1 / 3 \times 18$ h.a & $=6$ h.a \\
\hline 2 saudara kandung perempuan & & 3 & Jumlah & $=36$ h.a \\
\hline
\end{tabular}

Sisa harta diberikan kepada ibu, kakek dan 2 saudara kandung perempuan

\section{Sumber: Data Primer, diolah, 2017}

4. Harta warisan pewaris sejumlah 12 h.a. kakek dan 2 saudara kandung laki-laki. Ahli warisnya terdiri dari suami, ibu, Maka cara penyelesaiannya:

Tabel 8. Contoh Kasus Penghitungan Radd untuk Janda dan Duda 4

\begin{tabular}{|c|c|c|c|c|}
\hline Ahli Waris & Bagian & AM (6) & HW (12 h.a) & Penerimaan \\
\hline Suami (duda) & $1 / 2$ & 3 & $3 / 6 \times 12$ h.a & $=6 \mathrm{~h} . \mathrm{a}$ \\
\hline \multicolumn{5}{|c|}{$($ sisa harta 12 h.a -6 h.a $=6$ h.a $)$} \\
\hline $\mathrm{Ibu}$ & $1 / 6$ & 1 & $1 / 3 \times 6$ h.a & $=2 \mathrm{~h} . \mathrm{a}$ \\
\hline$\overline{\text { Kakek }}$ & $1 / 6$ & 1 & $1 / 3 \times 6$ h.a & $=2 \mathrm{~h} . \mathrm{a}$ \\
\hline \multirow[t]{2}{*}{2 saudara kandung laki-laki } & $1 / 6$ & 1 & $1 / 3 \times 6$ h.a & $=2 \mathrm{~h} . \mathrm{a}$ \\
\hline & & 3 & Jumlah & $=12 \mathrm{~h} \cdot \mathrm{a}$ \\
\hline
\end{tabular}

Sisa harta diberikan kepada ibu, kakek dan 2 saudara kandung perempuan

\section{Sumber: Data Primer, diolah, 2017}

5. Harta warisan pewaris sejumlah $\mathrm{Rp}$ dan ibu. Maka cara penyelesaiannya: $8.400,000,-$. Ahli warisnya adalah istri

Tabel 9. Contoh Kasus Penghitungan Radd untuk Janda dan Duda 5

\begin{tabular}{lcclll}
\hline \multicolumn{1}{c}{ Ahli Waris } & Bagian & AM (12) & \multicolumn{1}{c}{ HW (Rp 8.400.000,-) } & \multicolumn{1}{c}{ Penerimaan } \\
\hline Isteri (janda) & $1 / 4$ & 3 & $3 / 7 \times \mathrm{Rp} 8.400 .000,-$ & $=\mathrm{Rp}$ & $3.600 .000,-$ \\
\hline Ibu & $1 / 3$ & 4 & $4 / 7 \times \mathrm{Rp} 8.400 .000$ & $=\mathrm{Rp} 4.800 .000,-$ \\
\hline & & 7 & Jumlah & $=\mathrm{Rp}$ & $8.400 .000,-$ \\
\hline
\end{tabular}

Sisa harta diberikan kepada ibu

\section{Sumber: Data Primer, diolah, 2017}

6. Harta warisan pewaris sejumlah $\mathrm{Rp}$ $24.000,000,-$. Ahli warisnya adalah isteri (janda), nenek, dan 2 saudara seibu. Maka cara penyelesaiannya: 
Tabel 10. Contoh Kasus Penghitungan Radd untuk Janda dan Duda 6

\begin{tabular}{|c|c|c|c|c|}
\hline Ahli Waris & Bagian & $\mathbf{A M}(\mathbf{1 2})$ & HW (Rp 24.000.000,-) & Penerimaan \\
\hline Isteri (janda) & $1 / 4$ & 3 & $3 / 12 \times \operatorname{Rp} 24.000 .000,-$ & $=\mathrm{Rp} \quad 6.000 .000,-$ \\
\hline \multicolumn{5}{|c|}{ (sisa harta $\mathrm{Rp} 24.000 .000-\mathrm{Rp} 6.000 .000=\mathrm{Rp} 18.000 .000)$} \\
\hline Nenek & $1 / 6$ & 2 & 2/6 x Rp 18.000.000,- & $=\mathrm{Rp} \quad 6.000 .000,-$ \\
\hline \multirow[t]{2}{*}{2 saudara seibu } & $1 / 3$ & 4 & 4/6 x Rp 18.000.000,- & $=\operatorname{Rp} 12.000 .000$, \\
\hline & & 6 & Jumlah & $=\operatorname{Rp} 24.000 .000,-$ \\
\hline
\end{tabular}

Sisa harta diberikan kepada nenek dan 2 saudara seibu

\section{Sumber: Data Primer, diolah, 2017}

7. Harta warisan pewaris sejumlah Rp. isteri (janda), 8 anak perempuan, dan 6 48.000,000,-. Ahli warisnya adalah 4 nenek. Maka cara penyelesaiannya:

Tabel 11. Contoh Kasus Penghitungan Radd untuk Janda dan Duda 7

\begin{tabular}{|c|c|c|c|c|}
\hline Ahli Waris & Bagian & AM (24) & HW (Rp. 48.000.000,-) & Penerimaan \\
\hline 4 Isteri (janda) & $1 / 8$ & 3 & 3/24 x Rp. $48.000 .000,-$ & $=$ Rp. $\quad 6.000 .000,-$ \\
\hline \multicolumn{5}{|c|}{ (sisa harta Rp 48.000.000 - Rp 6.000.000 = Rp 42.000.000) } \\
\hline 8 anak perempuan & $2 / 3$ & 16 & 4/5 x Rp 42.000.000,- & $=$ Rp. 33.600.000,- \\
\hline \multirow[t]{2}{*}{6 nenek } & $1 / 6$ & 4 & 1/5 x Rp 42.000.000,- & $=$ Rp. $8.400 .000,-$ \\
\hline & & 20 & Jumlah & $=$ Rp. 48.000.000,- \\
\hline
\end{tabular}

Sisa harta diberikan kepada 8 anak perempuan dan 6 nenek

\section{Sumber: Data Primer, diolah, 2017}

8. Harta warisan pewaris berupa sawah seluas 12 h.a. Ahli warisnya adalah suami

(duda) dan 5 anak perempuan. Maka cara penyelesaiannya:

Tabel 12. Contoh Kasus Penghitungan Radd untuk Janda dan Duda 8

\begin{tabular}{lcclc}
\hline \multicolumn{1}{c}{ Ahli Waris } & Bagian & AM (12) & \multicolumn{1}{c}{ HW (12 h.a) } & Penerimaan \\
\hline Suami (duda) & $1 / 4$ & 3 & $3 / 12 \times 12$ h.a & $=3$ h.a \\
\hline (sisa harta 12 h.a -3 h.a $=9$ h.a $)$ & & & $=9$ h.a \\
\hline 5 anak perempuan & $2 / 3$ & 8 & $8 / 8$ x 9 h.a & $=12$ h.a \\
\hline
\end{tabular}

Sisa harta diberikan kepada 5 anak perempuan

Sumber: Data Primer, diolah, 2017

D. Pendapat Para Fuqaha atau adalah pendapat Sayyidina Utsman bin Affan Ulama tentang Radd untuk Janda r.a. $^{15}$ bahwa radd dapat diberikan kepada dan Duda

Pendapat para fuqaha atau ulama yang menyetujui tentang radd untuk janda dan duda semua ahli waris ashabul furudh, termasuk suami (duda) ataupun istri (janda) menurut perbandingan kadar bagian mereka masing- 
masing. Hal ini dikarenakan jumlah bagian ahli waris lebih banyak dari asal masalah, sehingga semua terkena pengurangan dalam penerimaan menurut perbandingan mereka masing-masing. Dengan demikian suami (duda) atau istri (janda) juga terkena pengurangan. Jika harta warisan yang dibagikan kepada ahli waris masih terdapat sisa (kelebihan) harta tanpa terkecuali, maka semua harus mendapat tambahan menurut perbandingan kadar bagian mereka masingmasing.

Meskipun pada prinsipnya suami (duda) dan istri (janda) tidak berhak menerima radd, tetapi dalam Undang-undang kewarisan Mesir yang mengambil pendapat dari Utsman bin Affan menetapkan bahwa adanya radd karena salah satu dari suami (duda) atau istri (janda) yang meninggal tidak memiliki ahli waris ashabah, ashabul furudh ataupun dzawil arham, maka salah satu dari suami isteri dapat menerima radd. Undang-undang Mesir Pasal 30 mengatur mengenai masalah radd untuk suami (duda) dan istri (janda). ${ }^{16}$ Undang-undang ini mengambil pendapat dari jumhur ulama tentang penetapan radd kepada dzawil furudh selain suami (duda) atau istri (janda). Aturan tersebut terdapat dalam Kitab Undang-undang Hukum Kewarisan Mesir Pasal 30, yaitu:

"Apabila furudh tidak dapat menghabiskan harta peninggalan dan tidak terdapat 'ashabah nasab, sisanya dikembalikan kepada selain suami istri dari golongan ashabul furudh, menurut perbandingan furudh mereka. Dan sisa harta peninggalan dikembalikan kepada salah seorang suami istri, bila tidak didapatkan seorang 'ashabah nasab atau salah seorang ashabul furud atau seorang dzawil arham." ${ }^{\prime 17}$

Penetapan radd kepada suami atau istri setelah adanya pembagian harta warisan kepada ahli waris $d z a w i l$ arham terjadi karena hubungan suami atau istri memiliki hak terhadap harta pasangannya daripada orangorang berhak lainnya. Dengan demikian, Kitab Undang-undang Hukum Warisan Mesir mengambil pendapat mayoritas ulama mengenai masalah radd kepada selain suami atau istri. Namun, mengecualikan satu kasus yang diambil dengan pendapat Utsman bin Affan, yaitu untuk salah satu dari suami atau istri ketika tidak ada ahli waris dzawil arham.

Sedangkan Fathur Rachman menyimpulkan bahwa ahli waris dzawil furudh yang berhak menerima radd yang terdapat dalam Kitab Undang-undang Hukum Kewarisan Mesir, diantaranya adalah ibu, nenek, anak perempuan, cucu perempuan dari anak laki-laki, saudari kandung, saudari seayah, saudara-saudari seibu, salah satu dari suami atau istri dengan syarat tidak ada ahli waris ashabah maupun ahli waris dzawil arham. Dengan demikian, salah satu dari suami atau istri dapat menerima kelebihan (sisa) harta jika tidak ada lagi ahli waris

16 Wahbah Al-Zuhaili, Fiqih Islam wa Adillatuhu: Hak-hak Anak, Wasiat, Wakaf, Warisan, Terjemahan Abdul Hayyie al-Kattani, dkk, (Jakarta: Gema Isnani, 2011), hlm. 436-437.

17 Fatchur Rahman, op.cit., hlm. 427. 
selain mereka. Jadi mereka diakhirkan dalam penerimaan kelebihan (sisa) harta atau radd.

Pemahaman konsep tentang radd menurut para ulama atau fuqaha memiliki perbedaan terkait dengan ahli waris yang menerima radd. Pendapat ulama yang menjelaskan tentang radd terbagi menjadi 2 (dua), yaitu ulama yang menerima radd dan ulama yang menolak radd. Para ulama yang menolak radd adalah Zaid bin Tsabit, Urwah ibnu Zubeir, Sulaiman ibu Yasirm Imam Syafii, dan Imam Maliki menjelaskan bahwa radd akan diberikan kepada baitul mal sebagai perwakilan masyarakat Islam. Penjelasan tersebut diperkuat dengan dalil Al Qur'an Surat An Nisaa ayat 14 dan hadits Nabi SAW. Sedangkan para ulama yang menerima adanya radd diperkuat dengan dalil Al Qur'an Surat Al Anfal ayat 75 dan hadits Nabi SAW, yaitu hubungan kekerabatan yang terjadi karena nasab jauh lebih kuat dan berpengaruh dalam hal kewarisan dibandingkan dengan hubungan perkawinan saja. Sehingga hubungan kekerabatan karena nasab dipandang lebih maslahah dengan tujuan membantu kehidupan ekonomi keluarganya Hak-hak yang sudah ditetapkan oleh Allah SWT tidak bisa diganggu gugat atau ditambah kurang begitu saja. Ternyata pendapat para ulama yang menerima adanya radd menimbulkan perbedaan juga, yaitu mengenai siapa-siapa ahli waris yang berhak menerima radd dan boleh tidaknya istri (janda) atau suami (duda) dalam hal kewarisan penerimaan radd.

Menurut pendapat para ulama atau fuqaha dalam penyelesaian masalah radd adalah radd dapat diberikan kepada semua ahli waris dzawil furudh kecuali suami (duda) atau isteri (janda). Hal tersebut dikarenakan hubungan kekerabatan nasab lebih diutamakan daripada hubungan perkawinan saja. Sebagaimana yang terdapat dalam Al Qur'an Surat Al Anfal ayat 75. Namun dilihat dari segi keumuman dalam Kompilasi Hukum Islam (KHI), lebih mengutamakan pendapat Utsman bin Affan yang menyatakan bahwa radd dapat diberikan kepada semua ahli waris tanpa terkecuali, termasuk suami (duda) ataupun istri (janda) dengan alasan bahwa pada saat terjadi kekurangan harta (aul), suami maupun istri juga ikut menanggungnya. Demi ditegakkannya keadilan hukum di dalam masyarakat, maka ketika adanya kelebihan (sisa) harta warisan, suami ataupun istri diikutsertakan sebagaimana partisipasi mereka dalam hal permasalahan kekurangan harta $(a u l)$.

Pemahaman konsep tentang radd yang seharusnya diterapkan di Indonesia adalah dengan cara melihat sistem kekerabatan dalam satu keluarga. Hal ini dikarenakan adanya peralihan hak tanggung jawab yang harus diemban sesudah pewaris meninggal dunia dan adanya kekayaan adat serta beragamnya kebiasaan dalam kehidupan masyarakat di Indonesia. Sehingga dalam penyelesaian permasalahan muncul berbagai kasus yang berbeda dengan memperhatikan beberapa kasus yang ada. Dengan demikian, pemahaman konsep tentang radd dalam masyarakat 
di Indonesia tidak boleh jauh dari tujuan diciptakannya hukum, yaitu kemaslahatan dan keadilan yang harus diwujudkan dalam masyarakat di Indonesia. Hal tersebut mengacu pada pertimbangan sistem kekerabatan, hak asuh dan pemeliharaan anak setelah salah satu dari istri atau suami meninggal dunia serta perubahan sosial yang tidak bisa diabaikan ketika radd akan diberikan kepada ahli waris tanpa adanya kejelasan mengenai siapa-siapa yang berhak menerimanya.

Selain Al Qur'an dan sunnah Nabi, ijtihad merupakan salah satu dasar hukum Islam yang utama secara lebih rasional untuk kemaslahatan, keadilan dan kepastian maka suami (duda) atau istri (janda) juga berhak dalam menerima radd, karena dalam keadaan apapun tidak mungkin seorang suami (duda) atau istri (janda) terhalang atau terhijab untuk mewaris. Sehingga dapat dilihat dalam konteks yang berbeda dengan menyesuaikan beberapa kasus yang ada tanpa mengesampingkan pendapat para ulama atau fuqaha dalam pengambilan keputusan.

\section{E. Pengaturan Radd dalam Kompilasi Hukum Islam (KHI)}

Kompilasi Hukum Islam Pasal 193 menjelaskan bahwa ahli waris yang berhak menerima sisa (kelebihan) harta atau radd adalah semua ahli waris ashabul furudh tanpa kecuali termasuk suami atau istri. ${ }^{18}$

Dengan demikian dalam hal pembagian harta warisan, jika terjadi kelebihan (sisa) harta setelah diambil dari ahli waris ashabul furudh dan tidak ada ahli waris ashabah, maka menurut Kompilasi Hukum Islam (KHI) kelebihan (sisa) harta tersebut akan diberikan kepada semua ahli waris ashabul furudh, termasuk suami (duda) dan istri (janda). Sehingga menjadi konsekuensi bagi suami (duda) atau istri (janda) dalam masalah radd jika akan mendapatkan tambahan harta warisan.

Sikap tegas yang diambil dalam Kompilasi Hukum Islam (KHI) lebih mengutamakan kemaslahatannya untuk penyelesaian pembagian harta warisan agar tidak menimbulkan suatu keraguan bagi pihak yang memiliki pedoman tersebut. Adapun kakek dan ayah keatas, dengan memperhatikan Kompilasi Hukum Islam (KHI) Pasal 177, yaitu:

"Ayah mendapatkan sepertiga bagian apabila pewaris tidak meninggalkan anak, bila meninggalkan anak, ayah mendapatkan seperenam bagian”.

Dengan demikian mengenai kakek dan ayah keatas, dalam Kompilasi Hukum Islam (KHI) juga memberikan sisa (kelebihan) harta dalam masalah radd. Hal tersebut dikarenakan tidak adanya suatu bagian sisa (kelebihan) atau ashabah terhadap mereka berdua.

\section{Simpulan}

Berdasarkan hasil penelitian dan uraian pembahasan pada bab-bab sebelumnya, maka penulis mengambil kesimpulan, yaitu sebagai 
berikut:

Dari seluruh pembahasan yang telah dijelaskan pada bab-bab sebelumnya, maka dapat dipahami bahwa pemahaman konsep radd dalam pandangan para ulama atau fuqaha memliki perbedaan terkait dengan ahli waris yang menerima radd. Pendapat mengenai radd terbagi menjadi 2 (dua), yaitu ulama yang menerima radd dan ulama yang menolak radd. Para ulama yang menolak radd yaitu Zaid bin Tsabit, Urwah ibnu Zubeir, Sulaiman ibu Yasirm Imam Syafii, dan Imam Maliki menjelaskan bahwa radd akan diberikan kepada baitul mal sebagai perwakilan masyarakat Islam. Penjelasan tersebut diperkuat dengan dalil Al Qur'an Surat An Nisaa ayat 14 dan hadits Nabi SAW. Sedangkan para ulama yang menerima radd diperkuat dengan dalil Al Qur'an Surat Al Anfal ayat 75 dan hadits Nabi SAW, yaitu mengenai hubungan kekerabatan yang terjadi karena nasab jauh lebih kuat dan berpengaruh dalam hal kewarisan dibandingkan dengan hubungan perkawinan saja. Sehingga hubungan kekerabatan nasab dipandang lebih maslahah dengan tujuan membantu kehidupan ekonomi keluarganya. Ternyata pendapat para ulama yang menerima radd menimbulkan perbedaan juga, yaitu mengenai siapa-siapa ahli waris yang berhak menerima radd dan boleh tidaknya istri (janda) atau suami (duda) dalam hal kewarisan penerimaan radd.

Menurut pendapat para ulama dalam penyelesaian masalah radd adalah radd dapat diberikan kepada semua ahli waris dzawil furudh kecuali suami (duda) atau istri (janda), karena hubungan kekerabatan nasab lebih diutamakan daripada hubungan perkawinan saja. Namun dilihat dari segi keumuman dalam Kompilasi Hukum Islam (KHI), lebih mengutamakan pendapat Utsman bin Affan yang menyatakan bahwa radd dapat diberikan kepada semua ahli waris tanpa terkecuali, termasuk suami (duda) ataupun istri (janda) dengan alasan bahwa pada saat terjadi kekurangan harta $(a u l)$, suami ataupun istri juga ikut menanggungnya. Demi ditegakkannya keadilan hukum di dalam masyarakat, maka ketika adanya kelebihan (sisa) harta warisan, suami ataupun istri diikutsertakan sebagaimana partisipasi mereka dalam hal permasalahan kekurangan harta $(a u l)$.

Pemahaman konsep tentang radd yang seharusnya diterapkan di Indonesia adalah dengan cara melihat sistem kekerabatan dalam satu keluarga, karena adanya peralihan hak tanggung jawab yang harus diemban sesudah pewaris meninggal dunia dan adanya kekayaan adat serta beragamnya kebiasaan dalam kehidupan masyarakat di Indonesia. Sehingga dalam penyelesaian permasalahan muncul berbagai kasus yang berbeda dengan memperhatikan beberapa kasus yang ada. Dengan demikian, pemahaman konsep tentang radd dalam masyarakat Indonesia tidak boleh jauh dari tujuan diciptakannya hukum, yaitu kemaslahatan dan keadilan yang diwujudkan dalam masyarakat di Indonesia harus mengacu pada pertimbangan sistem kekerabatan, hak asuh dan pemeliharaan anak setelah salah satu 
dari istri atau suami meninggal dunia serta perubahan sosial yang tidak bisa diabaikan ketika radd akan diberikan kepada ahli waris tanpa adanya kejelasan mengenai siapa saja yang berhak menerimanya.

Selain Al Qur'an dan sunnah rasul, ijtihad merupakan salah satu dasar hukum
Islam yang utama secara lebih rasional untuk kemaslahatan suami (duda) atau istri (janda) berhak dalam menerima radd, karena dalam keadaan apapun tidak mungkin seorang suami (duda) atau istri (janda) terhalang atau terhijab untuk mewaris.

\section{DAFTAR PUSTAKA}

\section{Buku}

Abdurahman. Kompilasi Hukum Islam di Indonesia. Jakarta: Akademika Pressindo, 2004.

Afdol. Penerapan Hukum Waris Islam secara Adil. Surabaya: Airlangga University Press, 2003.

Al-Zuhaili, Wahbah. Fiqih Islam wa Adillatuhu: Hak-hak Anak, Wasiat, Wakaf, Warisan. Terj. Abdul Hayyie al-Kattani, dkk. Jakarta: Gema Isnani, 2011.

Ash-Shiddieqy, Hasbi. Fiqhul Mawaris. Jakarta: Bulan Bintang, 1973.

Ghazali, Hasan Yusuf. Al-Miras ala al-Mazahibul Arba'ah dirasatan watatbikhan. Ttp: Daar al-Fikr, 2003.

Hamid, Abdul dan Muhammad Muhyiddin. Ahkam Al-Mawarits fi Al-Syari'ah Al-Islamiyah'ala

Madhahib

Al-Arba'ah. Terj. Wahyudi Abdurrahim. Jakarta: Pustaka al-Kautsar, 2006.

Hamid, Abdul dan Muhammad Muhyiddin. Ahkam Al-Mawarits fi Al-Syari'ah Al-Islamiyah'ala
Al-Arba'ah. Terj. Wahyudi Abdurrahim. Jakarta: Pustaka al-Kautsar, 2006.

Komite Fakultas Syari'ah Universitas Al-Azhar Kairo. Hukum Waris. Terj. Addys al-Alizar, Fathurrahman. Jakarta: Senayan Abadi Publishing, 2004.

Kuzari, Akhmad. Sistem Asabah: Dasar Pemindahan Hak Milik atas Harta Tinggalan. Jakarta: Raja Grafindo Persada, 1996.

Maruzi, Muslich. Pokok-Pokok Ilmu Waris. Cetakan Ke-dua. Jakarta: Pustaka Amani, 1981.

Mughniyah, Muhammad Jawad. Fiqh Lima Mahzab. Terj. Afif Muhammad, Jakarta: Basri Press, 1994.

Muhammad Ali As-Shabuni, Ilmu Hukum Waris Menurut Ajaran Islam. Surabaya: Mutiara Ilmu, 1388.

Qudamah, Ibnu. Al-Mughni. Juz 7. Beirut: Dar al-Kutub al-Ilmiyah, t.th.

Rahman, Fatchur. Ilmu Waris. Bandung: Al Ma’rif, 1981. 
Usman, Usman Suparman dan Yusuf Somawinata. Cetakan Ke-dua. Fiqh Mawaris Hukum Kewarisan Islam. Jakarta: Gaya Media Pratama, 2002.

\section{Jurnal}

Murlisa, Lia. "Ahli Waris Penerima Radd Menurut Kompilasi Hukum Islam dan Relevansinya dengan Sosial Kemasyarakatan". Jurnal Ilmiah ISLAM FUTURA, Vol. 14. No. 2, (Februari 2015): 281-297.

\section{Thesis}

Zahari, Ahmad. "Kewarisan Kompilasi Hukum Islam serta Persamaan dan Perbedaannya dengan Hukum Kewarisan Syafii dan Hazairin”. Thesis Pasca Sarjana Universitas Diponegoro. Semarang: UNDIP, 2005. Tidak Dipublikasikan.

\section{Peraturan Perundang-undangan}

Undang-Undang Dasar Republik Indonesia 1945.

Undang-Undang Nomor 1 Tahun 1974 tentang Perkawinan.

Instruksi Presiden Nomor 1 Tahun 1991 tentang Kompilasi Hukum Islam.

Burgeliijk Wetboek (Kitab Undang-Undang Hukum Perdata). 